\title{
An organizational model and border port hinterlands for the China-Europe Railway Express
}

\author{
WANG Jiaoe ${ }^{1,2},{ }^{*}$ JIAO Jingjuan ${ }^{3}$, MA Li $^{1,2}$ \\ 1. Key Laboratory of Regional Sustainable Development Modeling, Institute of Geographic Sciences and \\ Natural Resources Research, CAS, Beijing 100101, China; \\ 2. College of Resources and Environment, University of Chinese Academy of Sciences, 100049, China; \\ 3. School of Economics and Management, Beijing Jiaotong University, Beijing 100044, China
}

\begin{abstract}
Facilities connectivity is a priority area for implementing the Belt and Road Initiative (BRI). The "China-Europe Railway Express" (CER Express) mode of transport organization links China with Europe by fast-track cargo rail. A major instance of facilities connectivity related to this project is an important practical and symbolic instance of BRI transport cooperation. The strategic significance of the CER Express and a number of operational issues are outlined, as are the implications of limited market potential for costs and competitiveness. A "hub-and- spoke" organizational model that can generate scale economies and reduce costs is proposed. To examine the establishment of an organizational model of this kind, the economic hinterlands of Alashankou, Erenhot, and Manzhouli are identified under high-, mediumand low-cost scenarios using an analytical methodology that determines distance and economic costs, and a number of transport hubs (that include Harbin, Zhengzhou, and Lanzhou) are identified. The results found that the cost of the routes from 314 Chinese cities to Moscow is the lowest via Manzhouli in the high- and medium-cost scenarios, but the routes change via Erenhot in the low-cost scenario. A number of policy recommendations should follow up.
\end{abstract}

Keywords: China-Europe Railway Express; cross-border transportation via land routes; Belt and Road Initiative; facilities connectivity; hub-and-spoke model

\section{Introduction}

The Belt and Road Initiative (BRI) proposed by China's President Xi Jinping, including two main components of "Silk Road Economic Belt" and the " 21 st Century Maritime Silk Road", is a new platform of economic and trade cooperation (Hu et al., 2014) that will contribute an orderly flow of goods and factors of production between BRI countries, an efficient allocation of resources, and deeper market integration (Liu, 2015). According to Vision and Ac-

Received: 2018-01-04 Accepted: 2018-03-05

Foundation: A Category of Strategic Priority Research National Program of the Chinese Academy of Sciences, No.XDA20010101; National Natural Science Foundation of China, No.41722103; Ministry of Education of Humanities and Social Science Youth Fund Project, No.17YJC790064

Author: Wang Jiaoe (1981-), Professor, specialized in transport and regional development. E-mail: jiaoewang@163.com

"Corresponding author: Jiao Jingjuan (1988-), PhD and Associate Professor, specialized in transport and regional development. E-mail: jiaojingjuan@163.com 
tions on Jointly Building Silk Road Economic Belt and 21st-Century Maritime Silk Road, the BRI proposes five cooperation priorities: policy coordination, facilities connectivity, trade facilitation, financial cooperation and people-to-people bonds (Liu and Dunford, 2016). Of these priorities, facilities connectivity aims to connect China with Central Asia, West Asia, South Asia, Europe and Africa, and to manage maritime transport risks (Strait of Malacca, Suez Canal and South China Sea) by developing overland transport (Vinokurov and Tsukarev, 2017).

The development of land routes connecting China with Europe dates back at least to 202-208 BC. Called the Ancient Silk Roads, these routes played a role not just in trade but also in cultural and other exchanges (Rodrigue et al., 2013). The Morden Silk Roads date from the 1990s, when the Lanzhou-Xinjiang railway was connected with the Turkestan-Siberia railway, forming the entire New Eurasian Land Bridge along which the international transportation of passengers and goods started in 1992. In 2011 China opened the China-Europe rail cargo transportation service (hereinafter the "China-Europe Railway Express" (CER Express)) from Chongqing, China to Duisburg, Germany. By November 2017, 35 Chinese cities had opened CER Express services to 34 European cities in 12 European countries. The CER Express is now an important cooperative land transportation platform and a major driver of economic exchange and trade between China and BRI countries.

In the wake of the rapid development of the CER Express, its operations, problems, benefits, and related policy issues have been examined from managerial and economic perspectives ( $\mathrm{Li}, 2016)$. A quantitative comparison of regional conditions, transportation costs, transportation time, and levels of service of all routes identified the Chongqing-Xinjiang-Europe route as the most economically viable ( $\mathrm{Fu}, 2016)$. Abstracting from the value of the goods transported, Mo et al. (2015) argued that the CER Express has an adequate economic hinterland. To ensure that the CER Express operates normally and cost effectively, other authors have called for an increase in the area served and speed and the creation of a brand (Chen et al., 2015; Xie, 2016). Operational problems exist in relation to the interconnection between installations, operational organization, transportation costs, and the facilitation of customs clearance (Wang, 2015). Most of these problems continue to make profitability an issue. For these reasons and to identify the requirements for regular and profitable operations in a market system, this research seeks to clarify the organizational model of CER Express operation, the size of hinterlands and potential hubs. The current situation is outlined in the next section. Section 3 explores possible organizational models, while Sections 4 and 5 present a model used to identify the extent of CER Express transportation hinterlands and hubs. Section 6 draws some conclusions.

\section{The current state of CER Express operations}

CER Express scheduled high-speed freight train services between China and countries along the "Silk Road Economic Belt" (mostly in Europe) utilizes a "five fixed-point scheduling system" (fixed locations, fixed routes, fixed train numbers, fixed time, and fixed price) for shipping containers or fully-laden carriages along the whole route. By making the most of its advantages over ocean transport such as relatively shorter distances and shipping times, CER Express offers a scheduled service for the transportation of high value-added goods to 
Europe and other places from China (Mo et al., 2015). Due to its fast speed, high level of safety, and short transport time, CER Express provides a novel channel for transporting commodities on the Eurasian continent and plays a key role in driving cross-border organization and agreements in BRI countries.

\subsection{Distinctive features of CER Express operations}

The quantity of CER Express operations has steadily increased, gradually becoming a mainstay of back-and-forth land transport along the "Silk Road." On March 19, 2011, the first CER Express service left Chongqing and travelled via the Alashankou border port crossing in Xinjiang through Central Asia to Europe. Called the "Chongqing-Alashankou-Europe Railway", it opened a new era for rail freight, providing an alternative to shipping by sea or air. Subsequently, many other cities opened routes to Central Asia and Europe via Alashankou, Manzhouli, Erenhot and Horgos. Included were the "Wuhan-Alashankou-Europe Railway" (2012), the "Chengdu-Alashankou-Europe Railway" (2013), the "Chengdu- Erenhot-Europe Railway" (2013), the "Zhengzhou-Alashankou-Europe Railway" (2013), the "Zhengzhou-Erenhot-Europe Railway" (2013), and the "Suzhou-Manzhouli-Europe Railway" (2013). The "Chongqing-Europe Railway," the "Chengdu-Europe Express Rail," the "Chang'an Line" (Xi'an to Europe), the "Wuhan-Europe Railway," and the "Zhengzhou-Europe Route" gradually established regular scheduled services. In the past six years, the total number of CER Express services has increased rapidly from 17 trains in 2011 to 3217 in the eleven months from January to November 2017. Inbound services started in 2014 , increasing to 1105 trains in 2017 , with $51.02 \%$ of the capacity of trains returning to China used in 2017. The sustained growth of outbound service trains will continue and will help the normal operation of the CER Express in future (Figure 1).

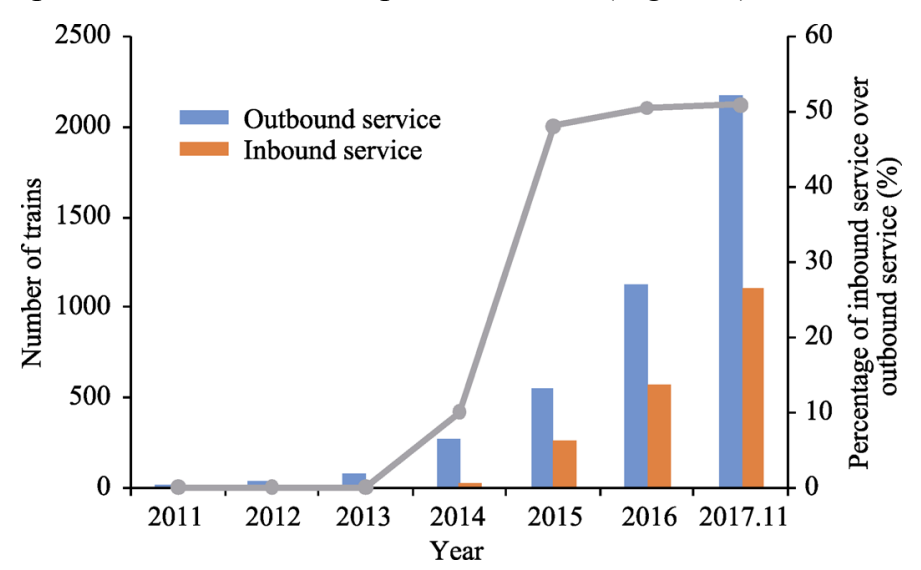

Figure 1 The growth of China-Europe Railway Express, 2011-2017

Nationwide, a system of regular scheduled CER Express operations is emerging along three (western, central, and eastern) operational corridors. An analysis of CER Express domestic routes reveals that there are 18 passing through the western border ports at Korgas and Alashankou, 17 passing through the eastern ports at Manzhouli and Suifenhe, and 4 passing through the central port at Erenhot. An analysis of the distribution of CER Express operations reveals that in 2015 , around $57 \%$ of scheduled trains passed through Alashankou, 
35\% passed through Manzhouli, and 8\% passed through Erenhot on their way to Central Asia and Europe. Of these, the key routes passing through Alashankou were the $\mathrm{Wu}-$ han-Europe, Chengdu-Europe, Chongqing-Europe, Zhengzhou-Europe, and HunanEurope lines. The key routes passing through Erenhot were the Chengdu-Europe, and the Zhengzhou-Europe lines. The key routes passing through Manzhouli were the HubeiEurope, Jiangsu-Europe, Hunan-Europe, Chongqing-Europe, Guangdong-Russia, and Guangdong-Europe lines. An analysis of the international routes reveals that the currently operational CER Express routes to Europe all utilize the northern and central routes, and the southern routes are yet to be utilized. Of the routes in use, the northern routes leave China at either Manzhouli or Erenhot, and cross the Siberian Continental Bridge in Russia to reach Europe via Moscow. The central routes exit China at either Alashankou or Korgas, and go through Kazakhstan to Moscow and then on to Europe. Both routes utilize Moscow as the key hub for entry into Europe.

Chinese cities with CER Express services are gradually extending from the western region towards the southeastern seaboard, while cities outside of China are gradually extending from western and central Europe towards eastern Europe, and even towards western and central Asia. In 2011, just one city (Chongqing) had CER Express services. In 2012, Wuhan opened a CER Express service to Czemelnik/Pardubice. In 2013, 4 additional cities opened CER Express services. Two of these (Guangzhou and Suzhou) are located in the eastern region of China and the other two (Zhengzhou and Xi'an) are in the central and western regions. In 2014, six cities added new services: Tianjin, Yiwu and Yingkou, located in the eastern coastal region, and Wuwei, Changsha and Hefei in the central and western regions. In 2015, 12 cities were added. In 2016, five of nine newly-added cities were in the eastern region, with the exceptions of Dongguan, Xiamen and Lianyungang these newly added cities were in the central and western regions. In 2017, four cities were added.

Till the end of November 2017, there were 57 CER Express routes linking 35 Chinese cities, including Xi'an, Chongqing, Wuhan, Beijing and Yiwu with 34 European cities in 12 countries. Amongst, 16 of 35 Chinese cities with CER Express services (a group that excluded Shanghai) were located in the eastern region, 9 in the central region and 10 cities (excluding cities in Tibet, Guizhou and Guangxi provinces which did not have services) were in the western region. Meanwhile, at national level, CER Express services to France and Holland in western Europe, Germany, Poland, the Czech Republic, and Slovakia in central Europe, Russia and Belarus in eastern Europe, Spain in southern Europe, and Kazakhstan, Turkey, Afghanistan, Iran, Uzbekistan, and Mongolia in Asia had opened. At city level, 34 European cities had successively opened up CER Express services, starting with Duisburg (2011) and Melnik and Pardubice in the Czech Republic (2012), and extending to Warsaw and Lodz in Poland (2013), Hamburg (2013), Moscow (2013), and Zhem in Kazakhstan (2013).

\subsection{CER Express operational issues}

A number of operational technological and economic issues affect CER Express operations (Wang et al., 2017):

(1) A lack of systematic top-level design gives rise to competition between each CER Express line. Up to 2017, 35 Chinese cities had opened up westbound CER Express routes to 
Europe or Central Asia. All of these routes were operated and organized by local government. Operational effectiveness was adversely affected by a lack of central government coordination, of systematic design and of an overall plan and operational arrangements. Most of the CER Express routes had similar and coincident long-haul routes, leading potentially to a waste of capital and resources and inefficient capacity utilization.

(2) The sources of freight in China are dispersed and there is too little freight for the eastbound CER Express routes, rendering it uneconomic for transportation. Under the impact of the China-Europe trade structure, the industrial structure of the cities of departure, and the low costs of ocean shipping, the supply of freight for CER Express services is small and dispersed. Most CER Express services remain undersupplied with freight even when there is only one scheduled train per week, making it difficult to support regular operations. Meanwhile, the goods exported from Europe via rail to China comprise a small quantity of precision instruments, machinery, and high-quality apparel. Most of the scheduled trains are unable to reach capacity on the return journey, increasing unit transportation cost.

(3) Restrictions on the connectivity of logistics corridors increase operational costs. China and western Europe use standard gauge rail $(1435 \mathrm{~mm})$, whereas Russia, Mongolia, countries in Central Asia and other former Soviet countries use broad gauge $(1520 \mathrm{~mm})$. As rail gauges differ (Figure 2), most international China-Europe scheduled trains must undergo at least two transshipments. In addition shipments are often stopped at ports of entry due to loading restrictions or overloading using up a lot of time. Alongside the costs of border stops and transshipment, CER Express services add 50\% to the costs of slow trains, making operational costs much higher than for intermodal rail-ocean or river-ocean shipment.

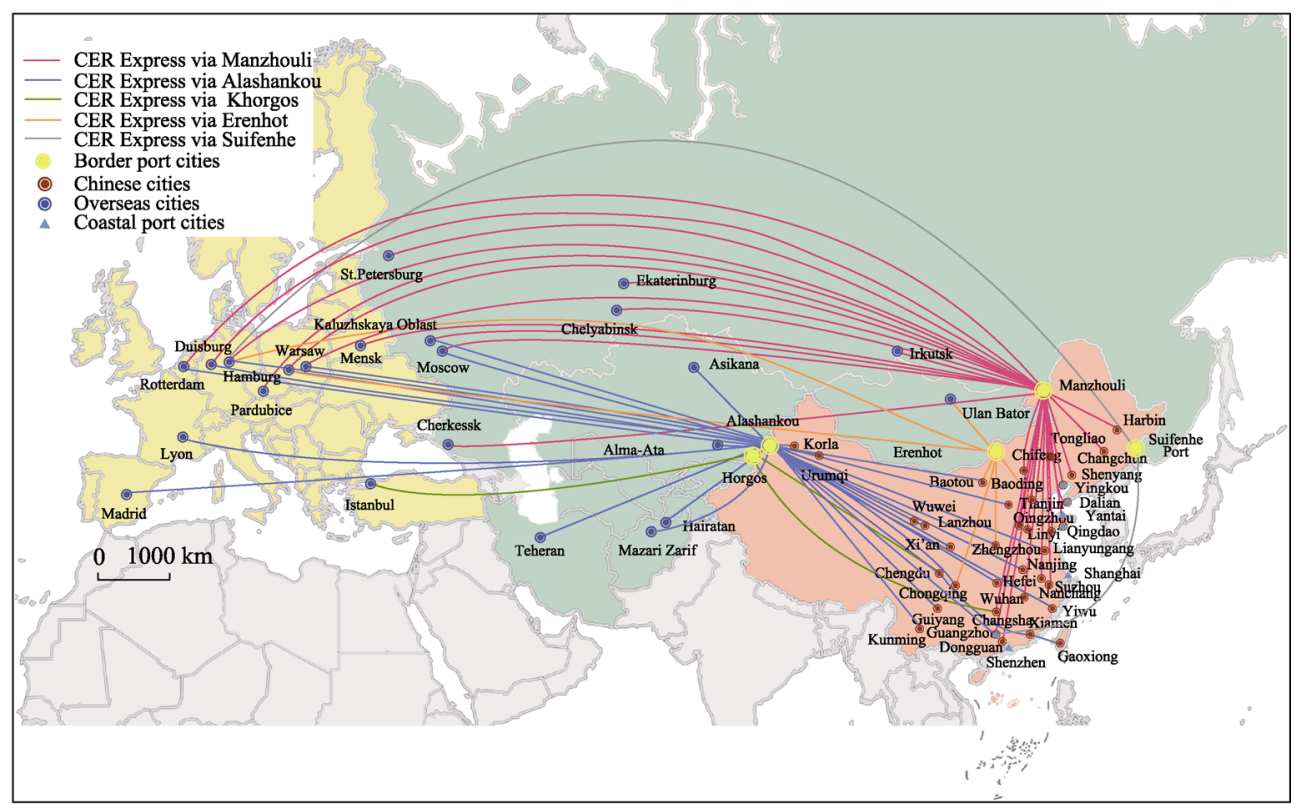

Figure 2 The departure and destination cities of China-Europe Express trains

(4) CER Express services rely on subsidies from local governments to cover losses. At present, the vast majority of CER Express' operations require government subsidies. To guarantee operations and attract freight, all local governments have established subsidy 
schemes, stipulating that they will cover costs in excess of those of ocean shipping; these subsidies are around 2000-3000 US dollars per container at the minimum in 2014. Under these conditions, the costs of most scheduled transportation services are roughly equivalent to or slightly higher than those of ocean shipping, although CER Express services takes less time. If local government did not provide subsidies, all CER Express routes would find it difficult to remain operational. In addition, CER Express services now face competition from Russia's "Iron Silk Road" which utilizes the Trans-Siberian Express (Lee, 2004).

Consequently, to establish regular and cost effective services the CER Express must reduce costs, increase market competitiveness and increase demand, making it essential to identify a rational and effective organizational model and identify the economic hinterlands of border ports and network hubs and nodes.

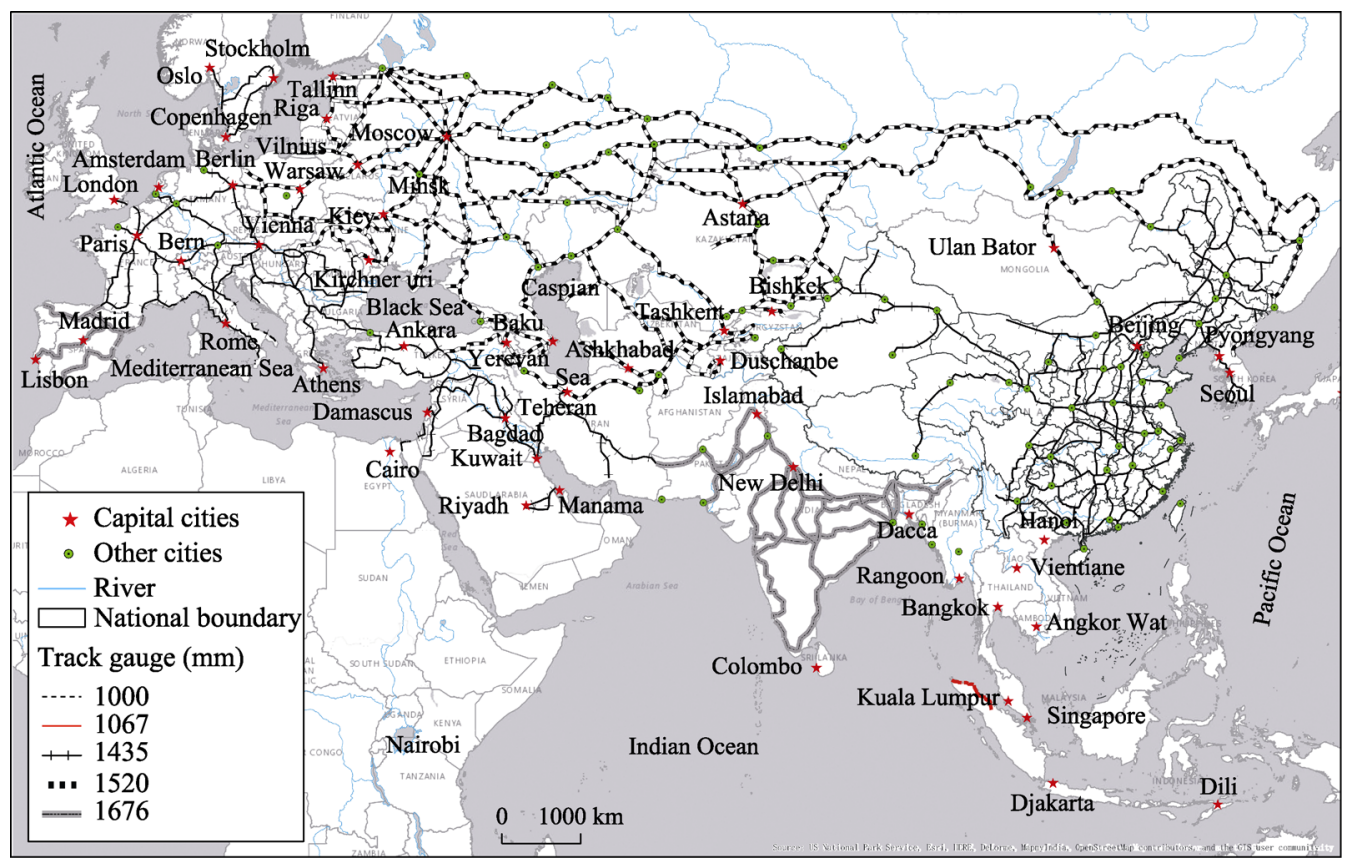

Figure 3 Distribution of rail track gauges by size in BRI countries

\section{An organizational model for CER Express services}

CER Express services are affected by the standards and technological level of rail infrastructure and equipment, by operational organization and policies in each of the countries involved, and by the complicated structure of regional geopolitics (Xu, 1997; Otsuka, 2001) as well as by high transportation costs that severely limit the international transportation of freight via rail between China and Europe, Central Asia, and Russia (Xu, 1997). Even though CER Express transportation costs have now dropped from US\$9000 per standard container to US\$6000, costs are still high when compared to ocean shipping. Thus, rational organization and regular high frequency scheduling of freight are keys to long-term and stable operations. At present, an irregular supply of freight, uncertainties for freight forwarders, and companies reneging on their contracts to carry freight are major issues impeding smooth full capacity operations. 
There are three models of the spatial organization models of rail and air transportation networks (Jin et al., 2005; Wang, 2008): point-to-point, multi-station, and hub-and-spoke systems (Figure 4):

(1) The point-to-point organizational model involves direct high-speed connections between the source of freight and the market for it. This model is suited to cities with an adequate supply of freight, and generates sufficient returns from supply and market areas that are the smallest in scope.

(2) The multi-station dependency model involves stopping one or many times between the point of departure and destination, picking up goods along the way. Stopping compensates for a lack of freight at the point of departure, and results in a beads-on-a-string spatial organization model. This model can meet the transportation needs of cities along the railway route, but is slower due to stopping, loading, and unloading with adverse effect on the efficiency of freight transport.

(3) The hub-and-spoke system combines a "central hub" and a "network of spokes" with a variety of modes of communication to ensure that "flow" costs are minimized. This spatial networking model is economical and convenient (Jin et al., 2005), and is suited to regions where the source of freight is relatively dispersed, with hubs and nodes used to reduce the costs and increase the scale economies associated with the collection and distribution of goods.

As the supply of freight for CER Express routes is relatively dispersed, a hub and spoke model can raise operational efficiency. In particular, by fixing scheduled times and core destinations, localities share routes and combine transport operations. For each point of departure collection and distribution hubs and nodes are identified according to how economical they are in terms of both time and money. Once this new organization model is established, goods are transported to a border port. After clearing customs these goods are sent to a hub city abroad, and from there they are transported onwards to their destinations. In this arrangement, hubs perform the function of organizing, collecting, and distributing goods. As the CER Express involves cross-border transportation, the choice of border ports has a direct bearing on transport efficiency of transportation and also plays a key role in the selection of hubs. The rest of this article will therefore dwell on these issues.

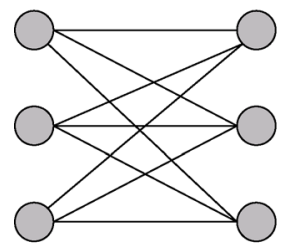

(a) point-to-point organizational model

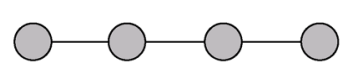

(b) multi-station dependency model

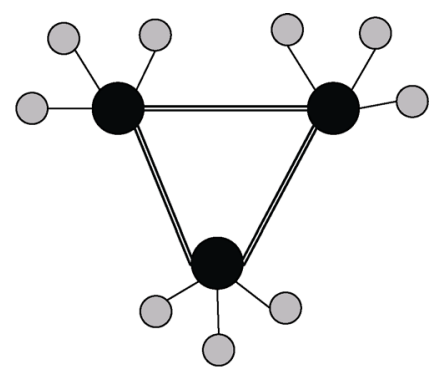

(c) hub-and-spoke system

Figure 4 The organizational models of railway freight network

\section{Computing the hinterlands of CER Express routes}

The CER Express has three transportation channels. The corresponding ports are Alashankou and Korgas in the west, Erenhot in the center, and Manzhouli and Suifenhe in the east. 
Due to the close proximity of Alashankou to Korgas, and of Manzhouli to Suifenhe, and the existence of relatively fewer routes through Korgas and Suifenhe compared with the others, Manzhouli, Erenhot, and Alashankouas were chosen and their economic hinterlands were identified.

\subsection{Research methodology}

A model of competition in multi-modal transportation networks (Mo et al. 2015) was used to identify port hinterlands. As there are differences in rail freight costs in different countries, transport costs were computed for routes from Chinese cities via the three border ports to Moscow, as lies at the intersection of all three CER Express channels. Transport costs include those of time and money. Time cost was calculated from data on and average speed of travel by the CER Express. Money costs include the fixed costs and the variable costs related to freight volume. Variable costs were determined by the volume of freight and distance of transport. The model itself was given by:

$$
T_{i}=D_{i} / S ; C_{i}=F+D_{i} / P
$$

where $T_{i}$ represents the shortest travel time by rail from a certain Chinese city $(i)$ to Moscow; $C_{i}$ indicates the lowest transportation costs for that route; $D_{i}$ is the shortest distance by rail transportation, calculated using the Network Analysis Tools in ArcGIS; $S$ indicates the average speed of the railway; $P$ represents the operational costs (traffic price) per unit of distance; $F$ indicates fixed expenses (including costs of loading and unloading, costs of technical tasks, and costs of processing documents and information). As there is little difference in these fixed expenses between the 57 routes through the three border ports, they were not taken into consideration in this study.

The transport costs via Alashankou and Manzhouli are relatively stable, standing at \$0.7/FEU.km and \$0.4/FEU.km, respectively, but the transport costs via Erenhot are yet to be settled. In this study three scenarios were considered: high, medium and low transport costs (Table 1). As the Mongolian railways are partially controlled by Russia companies, transport costs for the route from Erenhot via Mongolia and Russia were determined using rates used for routes via the Manzhouli and Alashankou ports, which are given different cost rates when passing through Russia. A high rate was set at $\$ 0.6 /$ FEU.km. As this rate is lower than that in Kazakhstan, this route has a cost advantage. A low rate from Erenhot via Russia and Mongolia was set at $\$ 0.4 /$ FEU.km. This rate is the same as the rate for goods leaving China via Manzhouli and travelling on the railway in Russia. This route potentially competes with the Trans-Siberian Express. A medium rate was set at $\$ 0.5 /$ FEU.km, since the distance from Erenhot traveling through Russia by the CER express was between the distance from Manzhouli and from Alashankou. We assume Russia will prefer to setting this cost rate for the CER from Erenhot according to the distance passing through Russia.

Table 1 Railway freight traffic charges through three border ports (\$/FEU.km)

\begin{tabular}{clllll}
\hline \multirow{2}{*}{ Border port } & \multicolumn{1}{c}{ Cost rate } & Border port & High & Cost rate & Medium \\
& China: 0.6 & & & & Low \\
Alashankou & Russia: 0.7 & & China: 0.6 & China: 0.6 & China: 0.6 \\
& Kazakhstan: 0.94 & \multirow{2}{*}{ Erenhot } & Russia: 0.6 & Russia: 0.5 & Russia: 0.4 \\
Manzhouli & China: 0.6 & & Mongolia: 0.6 & Mongolia: 0.5 & Mongolia: 0.4 \\
& Russia: 0.4 & & & & \\
\hline
\end{tabular}




\subsection{Results}

The study area comprises 310 prefecture-level administrative units and 4 municipalities connected to the Chinese railway system (Figure 5). The results based on travel distance indicated that the average shortest travel distance between the 314 cities and Moscow was via Alashankou followed by those via Erenhot and Manzhouli. The average travel distance from 314 cities to Moscow via Alashankou was $7990 \mathrm{~km}$, which was equal to $88 \%$ and $82 \%$ of the average distances via Erenhot and Manzhouli, respectively. Geographically, the shortest travel distance to Moscow for $82 \%$ of cities (259) was via Alashankou. These cities included all the cities in the central and western regions and most of the cities in the eastern region. For 18 cities mainly in northern Hebei Province, central Inner Mongolia Autonomous Region, and south western Liaoning province the shortest distance was via Erenhot. For 37 cities located mainly in the northeastern region the shortest route was via Manzhouli.

(a) Based on distance

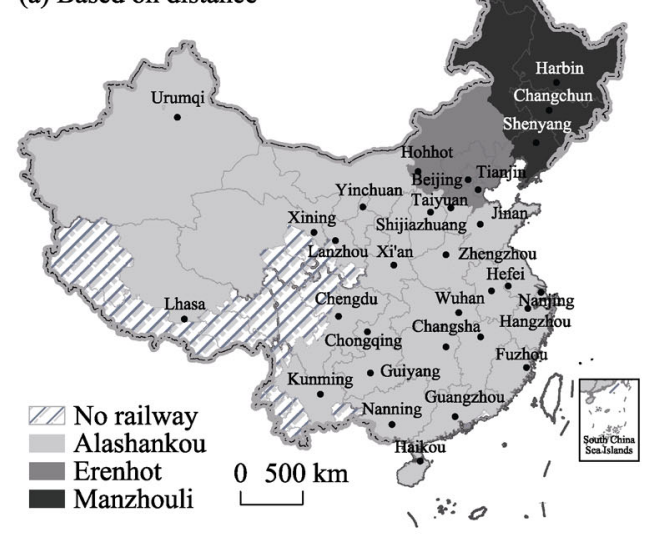

(c) Medium-cost scenario

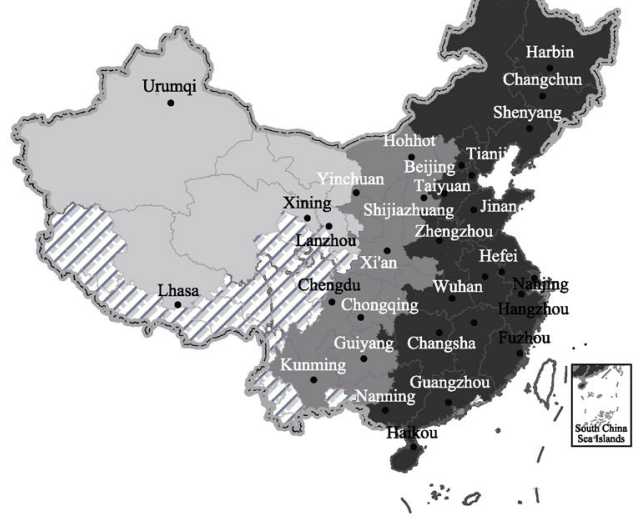

(b) High-cost scenario

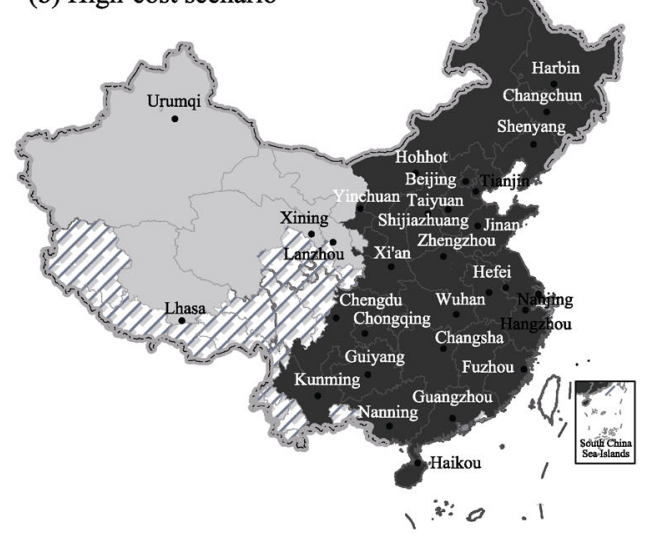

(d) Low-cost scenario

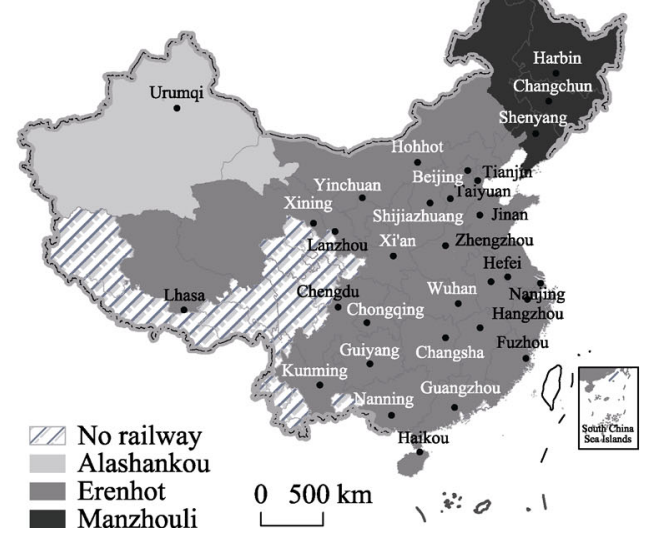

Figure 5 Economic hinterlands of the three border ports, as determined by distance and travel cost considerations

In the high- and medium-cost scenarios, average travel cost from Chinese cities to Moscow was the lowest via Manzhouli. In the low-cost scenario it was the lowest via Erenhot. More specifically, in the high-cost scenario, the average travel cost from 314 cities to Moscow via Manzhouli was $87 \%$ and $84 \%$, respectively, of that via Alashankou and Erenhot. In the medium-cost scenario the corresponding values were $87 \%$ and $95 \%$, respectively. In the 
low-cost scenario, the average travel cost for all cities via Erenhot to Moscow was just 78\% and $90 \%$, respectively, of those via Alashankou and Manzhouli. The economic hinterland of three border ports changed along with the transport cost rate. In the high-cost scenario, costs were minimized for the vast majority of cities on the route via Manzhouli. For only 29 north western cities transport via Alashankou was cheaper. In the medium-cost scenario, the economic hinterland of Alashankou was the same as in the high-cost scenario. However the economic hinterlands of Erenhot included an additional 74 cities, mainly located in provinces of Yunnan, Sichuan, Shaanxi and Shanxi, as well as Chongqing Municipality and autonomous regions of Inner Mongolia and Ningxia, with the rest remaining in Manzhouli's economic hinterland. In the low-cost scenario, the economic hinterland Erenhot extended further east and west to include $84 \%$ of cities, while the economic hinterlands of Alashankou and Manzhouli were reduced to 14 and 36 cities, respectively. Overall, the spatial distribution of the economic hinterlands of different ports was heavily influenced by the travel cost rate. In all the three scenarios, the cities in Xinjiang lay in the economic hinterland of Alashankou, while most cities in Northeast China lay within Manzhouli's economic hinterland; the cost minimizing border ports for the remaining cities changed with changes in the transport cost rate. A unified pricing system and government priorities would help to form a rational organization of CER Express.

\section{Identifying hubs of CER Express}

\subsection{Hub candidates}

Railway ports and marshalling stations are technical determinants of railway hub allocation, directly affect CER Express traffic distribution, the duration of clearance procedures and the efficiency of train make-up and constrain railway hub construction. By the end of 2016, there were twenty formal railway ports and eight temporary railway ports in China, located in 27 cities. Meanwhile, there were 15 networking marshalling stations, 17 regional marshalling stations and 17 local marshalling stations in 44 cities (Table 2).

Table 2 Railway ports and marshalling yards in China

\begin{tabular}{|c|c|c|c|}
\hline Railway port & City & $\begin{array}{c}\text { Marshalling } \\
\text { station }\end{array}$ & Station \\
\hline Formal & $\begin{array}{l}\text { Dongguan, Guangzhou, Shenzhen, } \\
\text { Foshan, Zhaoqing, Pingxiang, Zheng- } \\
\text { zhou, Suifenhe, Harbin, Tumen, } \\
\text { Hunchun, Ji'an, Dandong, Manchuria, } \\
\text { Erenhot, Alashankou, Hekou, Beijing, } \\
\text { Shanghai, Horgos }\end{array}$ & Networking & $\begin{array}{l}\text { South Harbin, West Shenyang, South } \\
\text { Shenyang, Shanhaiguan, Changchun, } \\
\text { Shijiazhuang, West Jinan, North } \\
\text { Xuzhou, North Fuyang, East Nanjing, } \\
\text { Nanxiangm, Yingtan, North Zhangzhou, } \\
\text { North Zhuzhou, North Xiangfan etc. }\end{array}$ \\
\hline \multirow[t]{2}{*}{ Temporary } & \multirow[t]{2}{*}{$\begin{array}{l}\text { Chongqing, Chengdu, Xi'an, Urumqi, } \\
\text { Wuhan, Donggaun, Yiwu, Ganzhou }\end{array}$} & Regional & $\begin{array}{l}\text { Sanjianfang, Siping, Harbin, Nan- } \\
\text { cang,West Datong, West Xiangtang, } \\
\text { West Jiang'an, South Wuchang, North } \\
\text { Hengyang, North Guangzhou, South } \\
\text { Liuzhou, East Xi'an, East Baoji, West } \\
\text { Lanzhou, East Chengdu, West } \\
\text { Chongqing, South Guiyang etc. }\end{array}$ \\
\hline & & Local & $\begin{array}{l}\text { Mudanjiang, South Tongliao, Meihekou, } \\
\text { North Taiyuan, Qiaosi, Genshanmen, } \\
\text { West Huainan, West Qingdao, Laizhou, } \\
\text { South Huaihua, West Baotou, Ying- } \\
\text { shuiqiao, South Wuwei, West Urumqi, } \\
\text { East Kunming, East Andong }\end{array}$ \\
\hline
\end{tabular}

Source: The table was compiled with data from http://www.chnrailway.com. 
In the light of the technical determinants of CER hub allocation, possible hubs are Beijing, Chengdu, Guangzhou, Harbin, Shanghai, Wuhan, Xi'an, Zhengzhou, Chongqing and Urumqi. As the 13th Five-year Plan for the development of national ports identified Lanzhou as a railway port, emphasizing its significance for CER Express western line, Lanzhou was added. Since Beijing, Shanghai and Guangzhou are already major transportation hubs, with developed transport systems, and are in particular coastal cities with advantages in maritime transportation, they were considered unsuitable for CER Express hubs (Wang et al., 2017), leaving eight candidate cities.

\subsection{Hub recommendation}

The collection-distribution ability of railway container centers, transportation hubs, highway hubs and logistics zones is crucial for the costs and benefits of CER Express services, and plays an important role in identifying and evaluating hubs. Factors affecting collection-distribution ability are intrinsic and exogenous. For example, an intrinsic factor is a distance between a local source of freight and ports. Exogenous factors are the hinterland geographies, the costs of distributing goods etc. As all of the eight candidate cities were railway container centers, national transportation hubs, first level national logistics zones and national highway hubs located along the trunk railway network, their collection-distribution abilities differed little, making the distance between ports and their hinterlands more important. In the case of the western corridor, Chongqing and Chengdu are adjacent. Also, goods to West need to be delivered via Lanzhou. Compared to Urumqi, Lanzhou is closer to the hinterland. Though both Lanzhou and Xi'an are located along the Longhai (Lianyungang-Lanzhou) line, only Lanzhou can collect and distribute goods in Southwest China giving it a larger hinterland. In the case of the Central corridor, CER Express operations via Zhengzhou were better than via Wuhan and its hinterland was wider. In the case of the East corridor, only Harbin had a railway hub, and had CER Express services operated. Lanzhou, Zhengzhou, and Harbin were therefore identified as initial West, Central and East corridor hubs. Other cities can subsequently function as hubs. At the same time, Lanzhou should focus on collecting and distributing goods from/to Northwest and Northeast China, Zhengzhou should be responsible for goods north of the Yangtze River, and Harbin should mainly collect and distribute goods in Northeast China.

\section{Conclusions and discussion}

With the development of the BRI, local governments are promoting the development of CER Express services, with a view to change China's traditional foreign trade transportation system. There is no doubt that the CER Express has provided a new platform for transporting goods between Asia and Europe, and has become an exemplar of transport cooperation between BRI countries. CER Express services have significantly improved the convenience and accessibility of cross-border rail freight transportation, and the border ports of Alashankou, Erenhot, and Manzhouli have their own varied hinterlands according to different transport cost rate. All CER Express via Alashakou to Moscow or other major cities in West Europe have the shortest travel distance. However, the results will vary if we discuss the travel cost which is more concerned by all enterprises along the BRI. According to calcu- 
lated hinterlands of CER Express services from the three border ports, the average travel cost from the 314 Chinese cities to Moscow are the lowest via Manzhouli in the high- and medium-cost scenarios, which is only $87 \%$ and $84 \%$ of the cost compared to the CER routes respectively through Alashankou and Erenhot in the high-cost scenario, and only $87 \%$ and 95\% of the cost compared to through Alashankou and Erenhot in the medium-cost scenario. In the low-cost scenario, the CER routes through Erenhot have the lowest travel cost. Besides, the 314 cities also have different priority routes via the three border ports for paying the lowest travel cost.

The reduced cost and improved accessibility by CER Express service easily leads people and the Chinese local governments to mistakenly think that trade between countries on the Eurasian continent will largely shift from ocean shipping to rail transportation. However, the future role of CER Express services in China's international trade transportation is limited, as it is constrained by the railway standards, the technological level of railway installations, operational organization and policy in every country involved, the complicated structure of regional geopolitics, and relatively high costs compared with ocean shipping. CER Express services are only profitable if used to transport suitable goods (such as high value-added products) or within a suitable regional contexts (such as interior regions far away from seaports). Adopting an effective organizational model for transportation (such as a hub-and-spoke network), setting up collection and distribution hubs, creating a unified brand, and bringing about an organized system for supplying freight for return journeys to China will help create economies of scale and expand the scope and viability of CER Express services. Meanwhile, along with the development of west China and the movement of some enterprises from the coastal to the inland areas of China, the demand of CER Express services will surely have a large increase in the near future. Nevertheless it is imperative the local governments clearly realize the objective fact that CER Express services will only ever serve to supplement ocean shipping and can never replace it.

\section{References}

Chen Rong, Shi Guojin, 2015. Thoughts on creating China-Europe block train with concept of "One Economic Belt, One Silk Road". Railway Transport and Economy, 37(11): 71-74. (in Chinese)

Fu Xinping, Zhang Xue, Zou Min et al., 2016. Analysis on economics of China-Europe block trains based on the value model. Railway Transport and Economy, 38(11): 1-5, 11. (in Chinese)

Gong Peiping, Song Zhouying, Liu Weidong, 2015. Commodity structure of trade between China and countries in the Belt and Road Initiative area. Progress in Geography, 34(5): 571-580. (in Chinese)

Hu Angang, Ma Wei, Yan Yilong, 2014. Connotation, definition and passage of "Silk-road Economic Belt" strategy. Journal of Xinjiang Normal University (Edition of Philosophy and Social Sciences), 35(2): 1-11. (in Chinese)

Jin Fengjun, Wang Chengjin, 2005. Hub-and-spoke system and China aviation network organization. Geographical Research, 24(5): 774-784. (in Chinese)

Lee J Y, 2004. Iron Silk Road: Prospects for a land bridge through Russia from Korea to Europe. Post-Soviet Affairs, 20(1): 83-105.

Li Jiafeng, 2016. Study on countermeasures of optimizing China-Europe block trains under "the Belt and Road" strategy. Railway Transport and Economy, 38(5): 41-45. (in Chinese)

Liu Weidong, 2015. Scientific understanding of the Belt and Road Initiative of China and related research themes. Progress in Geography, 34(5): 538-544. (in Chinese) 
Liu W D, Dunford M, 2016. Inclusive globalization: Unpacking China's Belt and Road Initiative. Area Development and Policy, 1(3): 323-340.

Lü Chengchao, Xu Qian, 2015. Space disequilibrium and interconnection policy for transportation infrastructure in new Silk Road Economic Belt. Journal of Shanghai University of Finance and Economics, 17(2): 44-53, 85. (in Chinese)

Mo Huihui, Wang Jiaoe, Song Zhouying, 2015. Economically suitable areas of China's transnational container transport by land in the Silk Road Economic Belt. Progress in Geography, 34(5): 581-588. (in Chinese)

Otsuka S, 2001. Central Asia's rail network and the Eurasian Land Bridge. Japan Railway \& Transport Review, 28: $42-49$.

Rodrigue J P, Comtois C, Slack B, 2013. The Geography of Transport Systems. 3rd ed. London, UK \& New York, NY: Routledge.

Song Zhouying, Che Shuyun, Wang Jiaoe et al., 2015. Spatiotemporal distribution and functions of border ports in China. Progress in Geography, 34(5): 589-597. (in Chinese)

Vinokurov E, Tsukarev T, 2017. The Belt and Road Initiative and the transit countries: An economic assessment of land transport corridors. Area Development and Policy, doi: 10.1080/23792949.2017.1385406.

Wang Chengjin, 2008. Spatial organizational network of Logistics Company in China. Acta Geographica Sinica, 63(2): 135-146. (in Chinese)

Wang J E, Cheng Y, Mo H H, 2014. The spatio-temporal distribution and development modes of border ports in China. Sustainability, 6(10): 7089-7106.

Wang Jiaoe, Jing Yue, Wang Chengjin, 2017. Study on better organization of China-Europe express train. Bulletin of Chinese Academy of Sciences, 32(4): 370-376. (in Chinese)

Wang Jiaoe, Wang Han, Jiao Jingjuan, 2015. China's international aviation transport to the Belt and Road Initiative area. Progress in Geography, 34(5): 554-562. (in Chinese)

Wang Yangkun, 2015. Status, problems and suggestions on development of Sino-Europe block trains. China Transportation Review, 37(Suppl.1): 70-75, 89. (in Chinese)

Xie Ye, 2016. Economic analysis and prospective of Sino-Europe block trains. Shipping Management, 38(7): 14-17. (in Chinese)

$\mathrm{Xu} \mathrm{S}, 1997$. The new Asian-Europe land bridge: Current situation and future prospects. Japan Railway \& Transport Review, 14: 30-33.

Zheng Lei, Liu Zhigao, 2015. Spatial pattern of Chinese outward direct investment in the Belt and Road Initiative area. Progress in Geography, 34(5): 563-570. (in Chinese)

Zou Jialing, Liu Chunla, Yin Guoqing et al., 2015. Spatial patterns and economic effects of China's trade with countries along the Belt and Road. Progress in Geography, 34(5): 598-605. (in Chinese) 